International Journal of Current Microbiology and Applied Sciences

ISSN: 2319-7706 Volume 6 Number 7 (2017) pp. 1962-1969

Journal homepage: http://www.ijcmas.com

Original Research Article

https://doi.org/10.20546/ijcmas.2017.607.233

\title{
Studies on Development of Squash from Mango (Mangifera indica L.) Pulp and Aloe Vera (Aloe barbadensis Miller.) Gel Blend
}

\author{
Mahendra Chaudhary $^{1 *}$, Bhagwan Deen ${ }^{1}$, Dharmendra Kumar Gautam ${ }^{2}$ \\ and Krishna Kumar Mishra ${ }^{1}$
}

\author{
${ }^{1}$ Department of Horticulture, N.D. University of Agriculture and Technology, Kumarganj, \\ Faizabad,-224229, U.P., India \\ ${ }^{2}$ Department of Horticulture, SVPUAT, Meerut-250110 U.P., India \\ *Corresponding author
}

\begin{abstract}
A B S T R A C T
Mango (Mangifera indica L.) and aloe vera (Aloe barbadensis Miller.) gel

Keywords

Manga,

Development,

Squash and Pulp

Article Info

Accepted:

21 June 2017

Available Online:

10 July 2017

have nutritional, medicinal and therapeutic values. The mango pulp and aloe vera gel are used to prepare palatable squash 25 per cent of blend consisting 75 per cent mango pulp and 25 per cent aloe vera gel, 50 per cent sugar, 1.25 per cent acidity and $350 \mathrm{ppm} \mathrm{SO}_{2}$. Observation on changes during storage revealed that TSS, acidity, reducing sugars, total sugars contents and browning increased whereas, Vitamin-C, non- reducing sugar and organoleptic score decreased continuously with storage period. The squash prepared from blend of mango pulp and aloe vera gel could be stored was up to five months under ambient conditions with acceptable quality.
\end{abstract}

\section{Introduction}

Mango (Mangifera indica L.) belongs to family Anacardiaceae, which is also known as Aam, king of fruits and National fruit of India. Mango is one of the exporting materials both in fresh and processed form and is being exported to U.K., U.S.A., France, Malasiya, Qatar and Singapore. Mango has also strong antioxidant, anti-lipid peroxidation, immunomodulation, cardiotonic, hypotensive, wound healing, antidegenerative and antidileutic activities. Young and unripe mango fruits, because of their acidic taste are utilized for culinary purposes as well as for preparing pickles, chutney, and amchur. Ripe mango fruits are utilized in preparing syrup, squash, juice, jam, jelly, preserve, etc. On the basis of analysis of more than 25 varieties of mango, it contains moisture 73.0-86.7 per cent, carbohydrate $11.6-24.3$ per cent, protein 0.3-1.0 per cent, fat $0.1-0.8$ per cent, minerals 0.3-0.7 per cent, vitamin A 650-25940 I.U., vitamin C 3-83 mg/100g, calcium 0.01 per cent, phosphorus 0.02 per cent and iron 4.5 mg/100 g. (Anonymous, 1966).

The Aloe vera (Aloe barbadensis Miller.) is perennial, succulent and drought resistant plant belonging to Liliacy family. It is also 
known as 'Ghrit-kumari' and 'Ghee-Kunwar' in Hindi. Aloe vera comes under food related products (Dubick and Michael, 1983) and is being used as an ingredient for functional food, mainly in the development of healthy drinks and beverages like tea (Singh et al., 2009). Aloe vera has been used in foods, medicine and cosmatics. Aloe vera was incorporated in food products like bread (Agrawal, 1985), jam and jelly (Niramon et al., 1996), Yagurt (Shin Yangseo et al., 1995), cheese (Steinka, 2001), infant formula (Benward, 2000), chewing gum (Jenkins, 2003) and beverages of orange, grape, cranberry, strawberry, raspberry, pineapple etc. (Malhotra et al., 2010). World Health Organization (WHO) estimated that 80 per cent of the population of developing countries rely on traditional medicine, mostly plant drugs for their primary health care needs (Malhotra et al., 2010). Other applications of aloe includes healing of wounds and burns, immunizing fresh bite damage, protection of skin damage from $x$-rays, lung cancer, inertia problem and reducing blood sugar in diabetes. They further reported that in 2008 Americans have spent almost 40 billion dollars on functional foods, drinks and supplements among which aloe vera products were the popular ones. Blending of mango pulp with aloe vera gel offers scope to develop healthy blended squash with improve colour, taste, flavor and over all acceptability. The findings of experiment would be useful for growers, processors, marketing agencies and consumers have intrest in beverage rich in mango and aloe vera properties.

\section{Materials and Methods}

\section{Raw materials}

The ripe fruit of mango of cultivar Amrapali and mature leaves of aloe vera cultivar Sim Sheetal were collected from the Main Experiment Station of Horticulture, Narendra Deva University of Agriculture and
Technology, Kumarganj, Faizabad and Central Institute of Medicinal and Aromatic Plants (CIMAP), Lucknow (India), respectively. The chemical characteristics of mango pulp and aloe vera gel used for the preparation of blended squash were analysed and presented in table 1 .

\section{Extraction of mango pulp and aloe vera gel}

The pulp from ripe mango fruits and gel from mature aloe vera leaves were extracted as per flow sheet shown in figures 1 and 2 , respectively.

\section{Preparation of squash}

Different five blend combination: 100 per cent mango pulp, 100 per cent aloe vera gel, 50 per cent mango pulp and 50 per cent aloe vera gel, 75 per cent mango pulp and 25 per cent aloe vera gel, 25 per cent mango pulp and 75 per cent aloe vera gel were prepared thereafter squash from each combination were made consisting 25 per cent blend, 50 per cent TSS, 1.25 per cent acidity and $350 \mathrm{ppm} \mathrm{SO}_{2}$. The technique used for the preparation of squash is shown in figure 3. The squash prepared from each combination of blend were evaluated on 9-point Hedonic scale by a panel of semi trained judges for their organoleptic quality to find out the best combination of mango pulp and aloe vera gel for squash preparation.

\section{Storage studies}

The 3 liters squash was prepared from the best combination of mango pulp and aloe vera gel, filled into the glass bottles of $750 \mathrm{ml}$ capacity leaving $2 \mathrm{~cm}$ head space, capped, and put under ambient condition for its storage studies. During storage data on changes in TSS, acidity, vitamin-C, reducing sugars, non-reducing sugar, total sugars, nonenzymatic browning and organoleptic quality were recorded at monthly interval. 


\section{Chemical analysis}

The ERMA made hand refractometer was used to measure total soluble solids at ambient temperature and readings were corrected at $20^{\circ} \mathrm{C}$ with the help of correction table (Ranganna, 2010) while known quantity of sample was titrated against $0.1 \mathrm{~N}$ sodium hydroxide solution using phenolphthalein drops as an indicator to determine acidity and acid content was calculated and expressed in per cent anhydrous citric acid.

To determine vitamin-C content sample was prepared in 3 per cent metaphosphoric acid solution and known volume of aliquot was titrated against 2, 6 dichlorophenol indophenols dye solution (Rangnna, 2010). The Fehling's solution A and B were used to determine reducing, non-reducing and total sugars (Lane and Eynone, 1923) whereas samle was prepared in alchohal and optical dencity (OD) was measured at $440 \mathrm{~nm}$ by ELICO made spectrophotometer in the determination of non-enzymatic browning (Ranganna, 2010).

A panel of 9 semi trained judges evaluated squash for its overall acceptability that included colour, flavour, taste and appearance on 9-point Hedonic scale (Amerine et al., 1965).

\section{Results and Discussion}

The present findings revealed that the mango pulp used in squash making contained 23.1 per cent total soluble solids, 0.31 per cent acidity, $16.00 \mathrm{mg} / 100 \mathrm{~g}$ vitamin-C, 7.08 per cent reducing sugars, 12.24 per cent nonreducing sugar, 19.32 per cent total sugars and $14.30236 \mathrm{mg} / 100 \mathrm{~g}$ total carotenoids whereas contained 2.20 per cent total soluble solids, 0.05 per cent acidity, 1.02 per cent reducing sugars, 1.08 per cent non-reducing sugar, 2.10 per cent total sugars and 2.35 $\mathrm{mg} / 100 \mathrm{~g}$ vitamin-C. A quality blended squash with 25 per cent blend of 75 per cent mango pulp and 25 per cent aloe vera gel with 50 per cent sugar, 1.25 per cent acidity and $350 \mathrm{ppm} \mathrm{SO}_{2}$ was organoleptically found best for preparation of blend squash. Similarly, Nath et al., (2005) reported that the squash prepared from mixing mandarin and ginger juice in ratio of 25:5 scored highest sensory attribute. Nidhi et al., (2007) also reported that squash blended with bael and guava was found highest acceptable.

Observation was recorded on changes during storage of blended squash indicated that total soluble solids increased gradually after one month of storage. Similar trend in change of TSS was found in guava squash (Pandey, 2004), bael squash (Prasad et al., 2006), bael and guava blended squash (Nidhi et al., 2007), Karonda squash (Deen and Singh, 2012). This increase in TSS content in blended squash during storage was probably due to the conversion of polysaccharides into sugar. In present findings the total acidity of blended squash increased gradually during storage period that could be attribute to degradation of pectic substances of products into soluble solids (Conn and Stumf, 1976).

The present findings are also in agreement with the observations of several earlier workers like Pandey (2004) on guava squash, Zulfakar et al., (2011) on seabuckthorn berries squash, Deen and Singh (2012) on Karonda squash, Nidhi et al., (2007) on bael and guava blended squash. The vitamin ' $\mathrm{C}$ ' content was decreased continuously during storage period which might be due to oxidation of ascorbic acid into dehydro ascorbic acid by oxygen. The finding is consistent with results reported by research papers authers: Nidhi et al., (2007) in bael and guava blended squash, Das (2009) in jamun squash, Zulfakar et al., (2011) in seabuckthorn berries squash, Deen and Singh (2012) in Karonda squash. 
Fig.1 Flow sheet for extraction of pulp from mango fruits

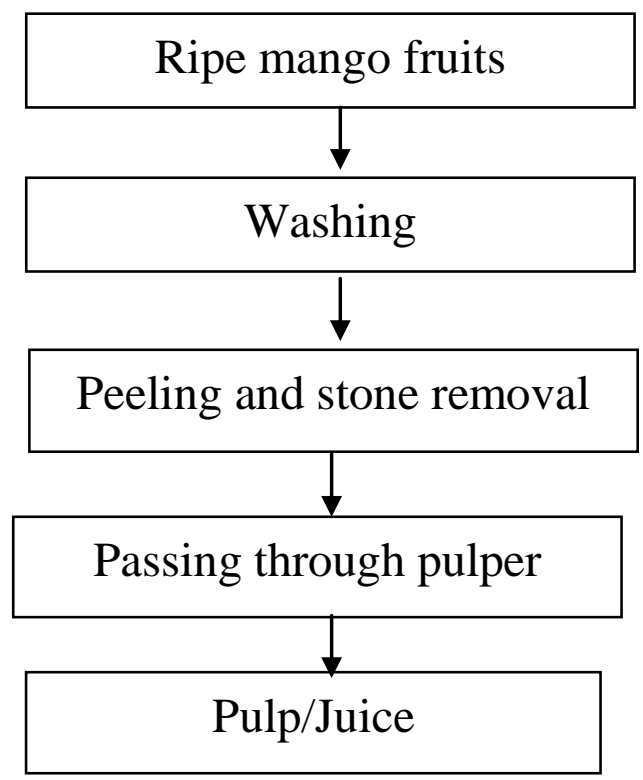

Fig.2 Flow sheet for extraction of gel from aloe vera leaves

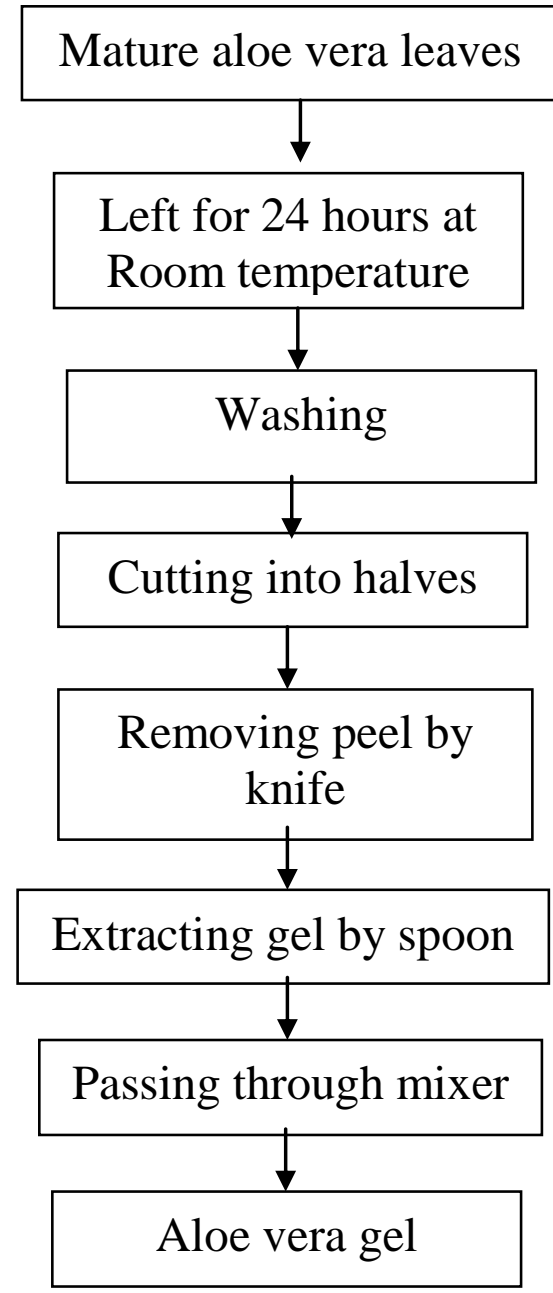


Fig.3 Flow sheet for preparation of mango + aloe vera blended squash

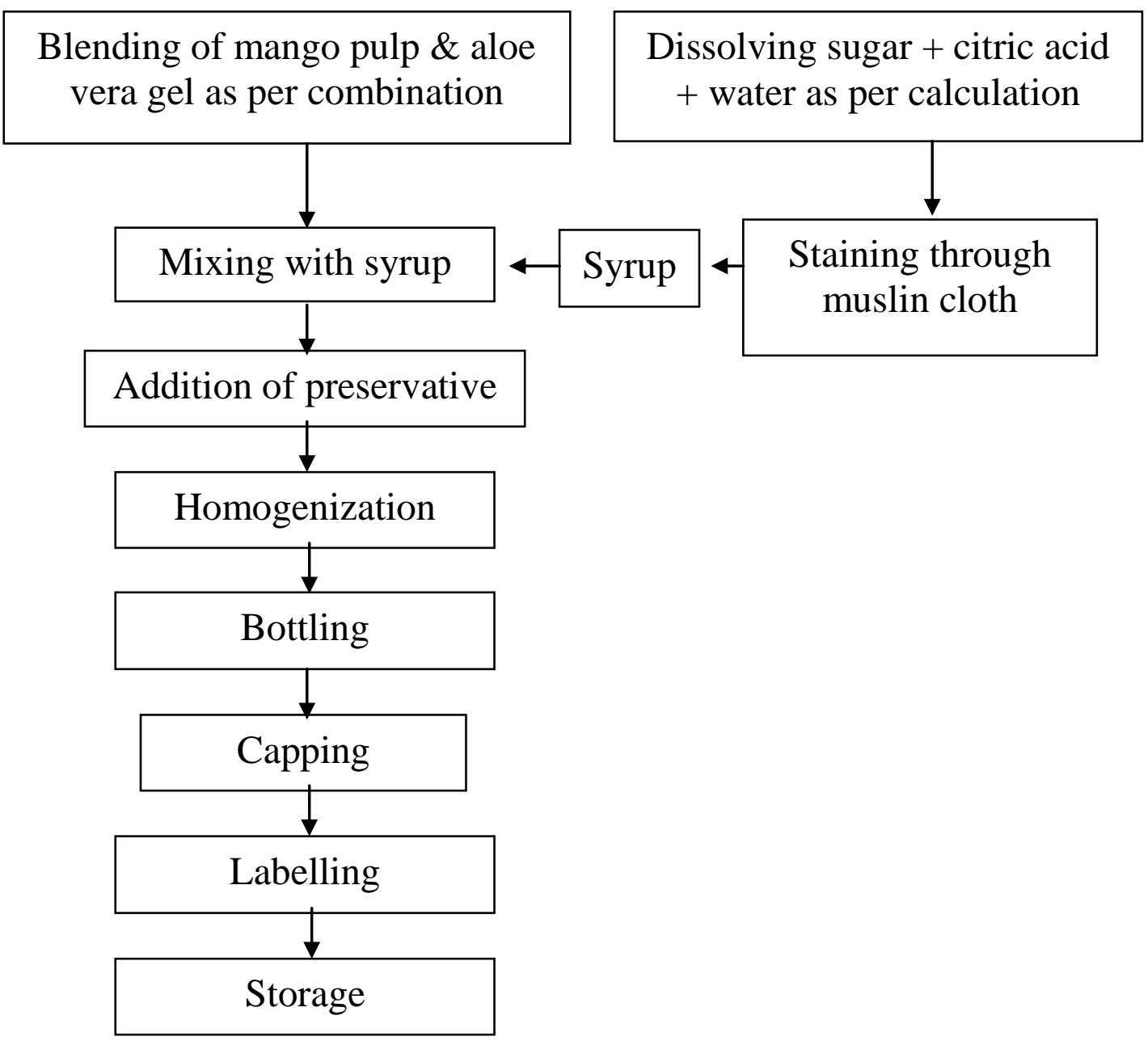

Table.1 Chemical characteristics of mango pulp as well as aloe vera gel

\begin{tabular}{|c|l|c|c|}
\hline S. No. & \multicolumn{1}{|c|}{ Chemical characteristics } & Mango pulp & Aloe vera gel \\
\hline 1 & Total soluble solids (\%) & 23.10 & 2.20 \\
\hline 2 & Acidity (\%) & 0.31 & 0.05 \\
\hline 3 & Vitamin-C (mg/100 g) & 16.00 & 2.35 \\
\hline 4 & Reducing sugars (\%) & 7.08 & 1.02 \\
\hline 5 & Non-reducing sugar (\%) & 12.24 & 1.08 \\
\hline 6 & Total sugars (\%) & 19.32 & 2.10 \\
\hline 7 & Total carotenoids (mg/100 g) & 14.30236 & - \\
\hline
\end{tabular}


Table.2 Organoleptic quality of squash prepared from different blends of Mango pulp and aloe vera gel

\begin{tabular}{|c|c|c|c|c|}
\hline \multirow{2}{*}{ Treatments } & \multicolumn{2}{|c|}{ Different combination of blends } & \multicolumn{2}{c|}{ Organoleptic quality } \\
\cline { 2 - 5 } & Mango pulp (\%) & Aloe vera gel (\%) & Score & Rating \\
\hline 1 & 100 & Nil & 7.75 & Like very much \\
\hline 2 & Nil & 100 & 6.25 & Like slightly \\
\hline 3 & 50 & 50 & 7.40 & Like moderately \\
\hline 4 & 75 & 25 & 8.00 & Like very much \\
\hline 5 & 25 & 75 & 7.15 & Like moderately \\
\hline \multicolumn{2}{r}{ CD at 5\% } & 0.74 & \\
\hline
\end{tabular}

Table.3 Changes in squash during storage period

\begin{tabular}{|c|l|l|c|l|c|c|c|c|c|}
\hline $\begin{array}{l}\text { Storage } \\
\text { period } \\
(\mathrm{months})\end{array}$ & $\begin{array}{l}\text { TSS } \\
(\%)\end{array}$ & $\begin{array}{l}\text { Acidity } \\
(\%)\end{array}$ & $\begin{array}{l}\text { Vitamin-C } \\
(\mathrm{mg} / 100 \mathrm{~g})\end{array}$ & $\begin{array}{l}\text { Reducing } \\
\text { sugars } \\
(\%)\end{array}$ & $\begin{array}{l}\text { Non- } \\
\text { reducing } \\
\text { sugar }(\%)\end{array}$ & $\begin{array}{l}\text { Total } \\
\text { Sugars } \\
(\%)\end{array}$ & $\begin{array}{l}\text { Browning } \\
(\mathrm{OD})\end{array}$ & $\begin{array}{l}\text { Organoleptic } \\
\text { quality }\end{array}$ \\
\hline 0 & 50.00 & 1.25 & 4.80 & 6.55 & 41.60 & 48.15 & 0.60 & 8.00 & LVM \\
\hline 1 & 50.00 & 1.38 & 4.66 & 7.49 & 41.05 & 48.54 & 0.60 & 7.80 & LVM \\
\hline 2 & 50.25 & 1.54 & 4.55 & 8.50 & 40.52 & 49.02 & 0.61 & 7.40 & LM \\
\hline 3 & 50.50 & 1.72 & 4.40 & 9.54 & 40.03 & 49.58 & 0.63 & 7.25 & LM \\
\hline 4 & 50.80 & 1.86 & 4.20 & 10.61 & 39.54 & 50.15 & 0.65 & 7.00 & LM \\
\hline 5 & 51.05 & 1.99 & 3.95 & 11.64 & 39.06 & 50.70 & 0.67 & 6.75 & LM \\
\hline CD at $5 \%$ & 5.33 & 0.12 & 0.41 & 0.89 & 4.85 & 4.93 & 0.06 & 0.74 & \\
\hline
\end{tabular}

LVM= Like very much, LM=Like moderately.

The study confirmed that that the reducing sugars and total sugars of blended squash increased continuously throughout entire period of storage. Similar observations were also observed in phalsa squash (Waskar and Kkurdiya, 1987), in bael and guava blended squash Nidhi et al., (2007), in Karonda squash Deen and Singh (2012), Whereas, non-reducing sugar of blended squash decreased continuously throughout the entire period of storage which might be because of inversion of non-reducing sugar.

Similarly, Wasker and Khurdiya (1987) in phalsa squash, Wasker and Deshmukh (1955) in pomegranate juice, Deen and Singh (2012) in Karonda squash were found reduction in non-reducing sugar (Table 3). Browning increased gradually in blended squash after one month of storage. This change could be mainly due to the non-enzymatic reaction with sugars and amino acids which leads to the formation of brown pigments. Similar results were reported by Rabbani (1992) in mango squash, Pandey (2004) in guava squash, Zulfakar et al., (2011) in seabukthorn berries squash, Deen and Singh (2012) in karonda squash.

The acceptability of blended squash in terms of organoleptic score decreased gradually during the storage period at room temperature (Table 2). Similar results on reduction in organoleptic quality have also been reported in kinnow, mandarin and ginger juice blended squash (Nidhi et al., 2008), mango squash (Kumari and Sandal, 2011) Karonda squash (Deen and Singh, 2012). 
In conclusion, Mango pulp and aloe vera gel have medicinal and therapeutic values. A palatability quality squah with 25 per cent blend consisting 75 per cent mango pulp and 25 per cent aloe vera gel was found best for preparation of squash containing 50 per cent sugar, 1.25 per cent acidity and $350 \mathrm{ppm} \mathrm{SO}_{2}$ squash could be stored up to five months under ambient condition with acceptable quality.

\section{References}

Agrawal, O. P. (1985). Prevention of anthromatous heart disease. Angiology, 36: 458-492.

Amerine, M.A.; Pangborn, R.M. and Roessler, E.B. (1965). Principle of sensory evaluation of food. Academic Press, London.

Anonymous (1966). Speacial Report Series, No. 4, I.C.M.R., New Delhi.

Benward, M. E. and Benward, W. (2000). Healthy body infant formula beverage and healthy body toddler formula beverage. US; United State Potent (US 6063433).

Conn, E.E. and Stumf, P.K. (1976). Outline of Biochemistry, Wiley Eastern Ltd., New Delhi.

Das, J.N. (2009). Studies on storage stability of jamun beverages. Indian Journal of Horticulture, 66 (4): 508-510.

Deen, B. and Singh, I.S. (2012). Development of Karonda (Carissa carandas L.) squash. Beverage and Food World, 39 (2): 37-39.

Dubick and Michale, A. (1983). Dietary supplements and health aids. A critical evaluation: Part 3: Natural Miscellaneous Products. Journal of Nutrition Education (USA), 26 (6): 259265.

Jenkins, J. (2003). Nutrition chewing gum.US; United State Patent
Application (US 2003/0157213 AI)

Publication.

Kumari, A. and Sandal, A. (2011). Quality evaluation of products prepared from local mango. Indian Journal of Agricultural Biochemistry, 24 (2): 131135.

Lane and Eyenone L. (1923). Determination of reducing sugars by means of Fehling solution with methylene blue indicator as an internal indicator. Journal Soc. Chem. India, 42: 32.

Malhotra, R.; Tyagi, S.M. and Saini, P. (2010). Studies on aloe vera a component of functional foods. Beverage and Food World. 37 (7): 3639.

Nath, A.; Yadav, D.S.; Pranabjyoti, Sharma and Dey, B. (2005). Standardization of ginger-kinnow squash and its storage. Journal of Food Science Technology, 42: 520-522.

Nidhi; Gehlot, R.; Singh, R.; Siddiqui, S. and Rana, M.K. (2007). Changes in chemical composition of bael-guava blend ready-to-serve beverage and squash during storage. Haryana Journal of Horticultural Sciences, 36 (1/2): 4648.

Nidhi, Gehlot, R.; Singh, R. and Rana, M.K. (2008). Changes in chemical composition of ready-to-serve of baelguava blended beverage during storage. Journal of Food Science and Technology (Mysore), 45 (4): 378-380.

Niramon, U.; Pannee, I. and Ekachai, S. (1996). Development of orange Aloe vera jam. Lampang Agriculture Research and Training Centre (Thailand) [Processing of the $13^{\text {th }}$ Rajmangla Institute of Technology Annual Conference]. Food Science and Home Economics, 94: 39-45.

Pandey, A.K. (2004). Study about the storage stability of guava beverages. Prograessive Horticulture, 36 (10): 
142-145.

Prasad, R.N. and Mali, P.C. (2006). Changes in physico-chemical characteristics of bael squash during storage. Scientific Horticulture, 10: 175-178.

Rabbani, A. (1992). Studies on Post-harvest technology of sucking mangoes. Ph.D. Thesis N.D. University of Agri. and Tech., Faizabad (U.P.).

Ranganna, S. (2010). Analysis and quality control for fruit and vegetable products, Tata Mc Graw-Hill Ltd., New Delhi.

Shin Yang, Seo; Lee, Kapsong; Leejung, Sung. And Lee, Cheriho. (1995). Preparation of Yogurt with added aloe vera and its quality characteristics. Journal of Korean Society of Food and Nutrition, 24 (2): 254-260.

Singh, Shiv; Kumar, Anil; and Shalini, Rachana. (2009). Studies on effect on preservation techniques and storage condition on TSS and $\mathrm{pH}$ of flavoured aloe vera juice. Beverage and Food World, 36 (12): 15-19.

Steinka, I. (2001). Possibility to apply aloe vera solution to optimize the quality of the lactic acid cheese. $8^{\text {th }}$ Egyptian Conference of Dairy Science and Technology held at the International Agriculture Centre, Cairo, Egypt, 235242.

Waskar, D.P. and Deshmukh, A.N. (1995). Effect of packaging containers on the retentions of pomegranate juice. Indian Food Packer, 41 (5): 5-8.

Waskar, D.P. and Khurdia, D.S. (1987). Processing and storage of phalsa beverages. Indian Food Packer, 41 (5): 7-11.

Zulfakar, Ali; Girish Korekar; Sunil Mundra; Ashish Yadav and Tsering Stobdan (2011). Quality attributes seabuckthorn squash during storage. Indian Journal of Horticulture, 68 (4): 479-483.

\section{How to cite this article:}

Mahendra Chaudhary, Bhagwan Deen, Dharmendra Kumar Gautam and Krishna Kumar Mishra. 2017. Studies on Development of Squash from Mango (Mangifera indica L.) Pulp and Aloe Vera (Aloe barbadensis Miller.) Gel Blend. Int.J.Curr.Microbiol.App.Sci. 6(7): 19621969. doi: https://doi.org/10.20546/ijcmas.2017.607.233 